\title{
Erratum to: The short form of the recombinant CAL-A-type lipase UM03410 from the smut fungus Ustilago maydis exhibits an inherent trans-fatty acid selectivity
}

Henrike Brundiek • Stefan Saß - Andrew Evitt •

Robert Kourist • Uwe T. Bornscheuer

Published online: 21 February 2012

(C) Springer-Verlag 2012

Erratum to: Appl Microbiol Biotechnol

DOI 10.1007/s00253-012-3903-9

The original publication of this paper unfortunately contained an error during copyediting. In line three of the Abstract section, the correct sentence must read:

The two lipases with the highest identity are a lipase from Sporisorium reilianum and the prototypic CAL-A.

The online version of the original article can be found under doi:10.1007/s00253-012-3903-9.

H. Brundiek $\cdot$ S. Saß $\cdot$ A. Evitt $\cdot$ R. Kourist $\cdot$

U. T. Bornscheuer $(\triangle)$

Institute of Biochemistry, Department of Biotechnology \&

Enzyme Catalysis, Ernst-Moritz-Arndt University of Greifswald,

Felix-Hausdorff Str. 4,

17487, Greifswald, Germany

e-mail: uwe.bornscheuer@uni-greifswald.de 